This is the version of the chapter accepted for publication published by Gorgias Press: https://www.gorgiaspress.com/ Accepted version downloaded from SOAS Research Online: http://eprints.soas.ac.uk/25265

\title{
Syriac manuscripts from Turfan: public worship and private devotion.*
}

\author{
International Syriac Language Project Conference \\ Institute of Oriental Manuscripts, St. Petersburg
}

2nd July 2014

\section{Dr. Erica C D Hunter (SOAS, University of London)}

The first decades of the twentieth century saw the 'great cultural game' played out by various European powers at Turfan, an oasis located approximately $150 \mathrm{~km} \mathrm{SE}$ of Urumqi, now in the Xinjiang Uighur Autonomous Province, western China. N. N. Krotkov, the Russian Consul-General at Urumqi, sent back 97 Syriac-script fragments that are currently housed in the Institute for Oriental Studies at St. Petersburg. ${ }^{1}$ The $2^{\text {nd }}$ and $3^{\text {rd }}$ German Turfan Expeditions, led by Albert von le Coq and Albert Grünwedel, discovered more than 500 Syriac fragments, as well 550 Sogdian, 1 Middle Persian, 3 New Persian and 52 Old Uighur fragments, all of which were written in the Syriac script. ${ }^{2}$ Most of the Syriac fragments came from the Church of the East monastery site of Bulayiq, on the outskirts of Turfan, but small quantities were also found at other sites in the oasis including Astana, Qocho, Qurutqa and Toyoq. All were transported to Berlin where they were preserved under glass plates and are now housed in three separate repositories: the Staatsbibliothek, the headquarters of the Turfanforschung in the Berlin-Brandenburg Akademie der Wissenschaft and the Museum für Asiatische Kunst in Dahlem, Berlin.

A wealth of material, opening new horizons in our knowledge of the Church of the East in Central Asia and China, has been released with the recent publication of 519 Syriac fragments that were found

\footnotetext{
* The author is grateful to the Staatsbibliothek zu Berlin-Preussicher Kulturbesitz for access and permission to reproduce images of the relevant fragments. All images are copyright Depositum der Berlin

Brandenburgischer Akademie der Wissenschaften in der Staatsbibliothek zu Berlin -Preussischer Kulturbesitz, Orientabteilung. Low resolution images of the SyrHT signature numbers are available on the International Dunhuang Project website: http://id.bk.uk/enter signature no. in the search box.

1 For further details see Elena N. Meshcherskaya, "The Syriac Fragments in the N. N. Krotkov Collection" in Turfan, Khotan und Dunhuang. Edited by Ronald E. Emmerick et al. (Berlin: Akademie Verlag, 1996, 221-7.

2 For further details about these expeditions see Albert von le Coq, Buried Treasures of Chinese Turkestan, trans. Anna Barwell (London, George Allen and Unwin Ltd: 1928); Mary Boyce, A Catalogue of the Iranian Manuscripts in Manichaean Script in the German Turfan Collection (Deutsche Akademie der Wissenschaften zu Berlin, Institut für Orientforschung, Veröffentlichung Nr. 45), (Berlin Verlag: 1960), ix-xxvii.
} 
at Turfan. ${ }^{3}$ The Syriac fragments, all of which are paper, range in size from mere scraps, the size of postage stamps, to complete bifolia. Regrettably, there are no complete Syriac manuscripts, hence there is an absence of colophon information which would have been very valuable for information regarding the dating and place(s) of their writing. Monks may have carried some works on the long journey from Mesopotamia, others may have been produced at the scriptoria of monasteries located in the great Central Asian metropolitanates: most notably Merv and Samarkand. Some fragments were undoubtedly written at the monastery at Bulayiq in the Turfan oasis. The fragments are tentatively dated, on palaeographic grounds, between the $9^{\text {th }}-13^{\text {th }}$ centuries, with a possible $14^{\text {th }}$ century terminus ad quem. ${ }^{4}$ The origins and the circumstances surrounding the monastery's foundation still remain unknown; it may have been founded in the $8^{\text {th }}$ or $9^{\text {th }}$ centuries, at the time of the Uighur kingdom whose capital was at Qocho in the Turfan oasis. Of course, it could have been founded even earlier, given that Syriac Christianity travelled along the Silk Route to the Tang imperial capital at Xian, where Alopen was received at court in 635.

The monastery at Turfan was probably just one of many institutions that were founded by the Church of the East following the introduction of Christianity into Central Asia in the $4^{\text {th }}$ and $5^{\text {th }}$ centuries from whence it spread along the Silk Routes to China. ${ }^{5}$ The legacy of the great Antiochean theological tradition is clearly recalled in the following passage that occurs in SyrHT 80, a liturgical fragment which is a combination of the Martyrs' Anthem for Friday and the Commemoration of John the Baptist:

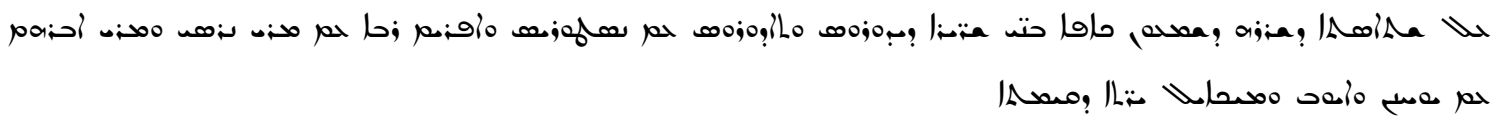

"Upon the foundation of the truth of Simon Peter (Cephas), the orthodox Diodore and Theodore with Nestorius, and the Great Ephrem with Mar Narsai and Mar Abraham with John, Job and Michael, the heirs of the resurrection."'6

${ }^{3}$ Erica C.D. Hunter and Mark Dickens (eds.), Syrische Handschriften, Teil 2. Texte der Berliner Turfansammlung. Syriac texts from the Berlin Turfan collection (Steiner Verlag, Stuttgart: 2014).

${ }^{4}$ Meshcherskaya, Syriac fragments, 226 suggests $13^{\text {th }}-14^{\text {th }}$ centuries. The last Buddhist communities in Turfan were forcibly converted to Islam in the $15^{\text {th }}$ century and whilst there is no conclusive evidence, it seems likely that any Christian communities would have been obliged to do likewise.

5 A Sogdian version of the Niceno-Constantinopolitan Creed of 381 -to which the Church the East adhered- was found at Turfan. See MIK III 59 (T II B 17 + T II B 28. For the Sogdian text and German translation: Friedrich W. K. Mu $\square$ ller, "Soghdische Texte I", SPAW 1912 (1913), 84-87. An English translation is supplied in Ian Gillman and Hans-Joachim Klimkeit, Christians in Asia before 1500 (London: Curzon, 1999), $252-3$.

6 SyrHT 80 (T II B 42 No. 1a) verso 1l.6-11. For a full description of the fragment, see Hunter and Dickens, Syrische Handschriften, 95-7. 
The specific mention of Nestorius, the erstwhile patriarch of Constantinople as well as its great theological exponents, Diodore of Tarsus and Theodore of Mopsuestia, 'the Interpreter', clearly anchors the monastery within the East Syrian theological tradition. Likewise, the citation of Mar Narsai and Mar Abraham (of Kashkar) who were traditionally associated with the renowned School of Nisibis, recall the pedagogic heritage of the Church of the East, whilst the reference to the 'Great Ephrem' evokes the golden age of Syriac Christianity prior to the schisms of the $5^{\text {th }}$ century.

A large proportion of the Syriac fragments from Turfan are liturgical and biblical. The Syriac Psalter was well represented at Turfan and its translation into a variety of languages including Sogdian and Middle Persian (Pahlavi) and New Persian highlights its dissemination amongst Iranian speaking populations. ${ }^{7}$ Likewise eight leaves of a Syriac Psalter that were transliterated into Uighur illustrate its dissemination amongst Turkic-speaking peoples in the area. ${ }^{8}$ Contrasting with the linguistic diversity of the Psalter are the large number of liturgical fragments that are written almost exclusively in Syriac. These supply invaluable information about the liturgy of the medieval Church of the East in its farflung dioceses. Many have been identified as coming from the Hudrā, the principal liturgical book of the Church of the East that contained "the variable chants of the choir for the divine office and the Mass for the entire cycle of the liturgical year". ${ }^{9}$ On the basis of palaeography and text-formatting criteria, 21 individual Ḥudrās have been identified amongst the Turfan fragments, but none is complete and the fragmentary nature of the texts has not facilitated comparative studies. Despite these limitations, the manuscripts are extremely important for the light that they shed onto the development of the Church of the East's liturgy. When Eduard Sachau published in 1905 single folios from three exemplars of the Hudrā, using photographs sent by von le Coq, ${ }^{10}$ he dated the manuscripts to the $10^{\text {th }}-12^{\text {th }}$ centuries, but suggested that they could be even older. ${ }^{11}$

${ }^{7}$ Ernest A.W. Budge, Histories of Rabban Hormį̂ the Persian and Rabban Bar- Tdtâ. 2 vols. (London: Luzac, 1902) vol. I, 609 records that Magians who were converted were taught "the psalms and hymns", vol. II: 350

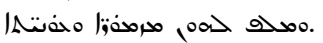

${ }^{8}$ Mark Dickens and Peter Zieme, "Syro-Uigurica I: A Syriac Psalter in Uyghur Script from Turfan" in Scripts Beyond Borders. A Survey of Allographic Traditions in the Euro-Mediterranean World, in Scripts Beyond Borders. Edited by Johannes den Heijer et al 291-328; Mark Dickens, "Syro-Uigurica II: Syriac passages in U338 from Turfan", Hugoye 16:2 (2013), 301-24.

9 William Macomber, "A List of the Known Manuscripts of the Chaldean Hudra”, Orientalia Christiana Periodica 36: 1 (1970), 120.

10 Eduard Sachau, "Litteratur-Bruchstu $\square$ cke aus Chinesisch-Turkistan”, Sitzungsberichte der Königlich Preussischen Akademie der Wissenschaften (Sitzung der philosophisch-historischen Classe von 23. November) XLVII (1905), 964-73.

${ }^{11}$ Sachau, Litteratur-Bruchstu $\square$ cke, 964. 


\section{Public Worship at Turfan: MIK III 45}

The manuscripts open significant windows into the stratum of public worship that took place at Turfan, and simultaneously show that it upheld the liturgical heritage of the 'mother church' in Mesopotamia. MIK III 45 is incomplete, but with 61 folios, is the most intact manuscript that has been discovered to date at the monastery. ${ }^{12}$ The actual title has been lost, however the contents of MIK III 45 divide into two parts. Fol. 1a-21a consist of Offices for the penitential season (fol. 1-7a) and Offices for the saints (fol. 7a-12b), the latter focusing on the commemoration of Mar Barshabba, Mart Shir and Zarvandokht who came from Seleucia-Ctesiphon to implant Christianity at Marv, the garrison town on the frontier of the Sassanid kingdom which became the most prestigious centre of the Church of the East, after the six metropolitanates in Mesopotamia. Fol. 13a-19a commemorate the third century Roman 'military-martyrs' Mar Sergius and Mar Bacchus and name Resafe (Sergiopolis) as their place of martyrdom. A common vigil for all saints sequels on fol. 19b-21a and concludes this first section.

The second part of MIK III 45, fol. 21b-61b, consists of a miscellany of items that shed invaluable light onto the rituals and liturgy, which were celebrated at Turfan:

- Rite for the consecration of a new church [fol. 21a-27b]

- Onyata (anthems/hymns) for ordinary days [fol. 27b-33a]

- Burial services for all orders (priests, deacons, حت مصدا bnay qeiama) [fol. 33a-53a]

- Miscellaneous prayers [fol. 52b-61b]

The rite for the consecration of a new church may point to an active outreach programme, both at Turfan or in more distant regions. The twenty folios devoted to burial services (fol. 33a-53a) include those for the bnay qeiama or 'Sons of the Covenant' and well as the clergy and laity. The usage of the term bnay qeiama by MIK III 45 in various places, points to an ascetic order associated with the monastery, but also evokes the greater environment of Syria during the third and fourth centuries. The significance of the northern Mesopotamian heritage of the Church of the East is epitomised by the recitation of the prayer of Barsauma, bishop of Nisibis, during the rite for the consecration of a new church. ${ }^{13}$ The disparate contents of fol. $21 \mathrm{a}-27 \mathrm{~b}$ suggest that they were a type of appendix or perhaps an 'in-service' manual that was a sequel to the main liturgical section found in fol. 1a-21a.

Recent C14 tests of MIK III 45, now housed in the Museum für Asiatische Kunst in Dahlem, Berlin have

12 MIK III 45 is complemented by 26 individual fragments, identified as coming from the same manuscript. MIK III 45 folios 20v-21r were edited by Sachau in 1905 as B26. See Sachau, Litteratur-Brucbstu $\square$ cke, 970-3. He already pointed out the concluding formula. See Peter Yoshira Saeki, The Nestorian Documents and Relics in China (Tokyo: Maruzen, 1937), ch. 15 for an English translation.

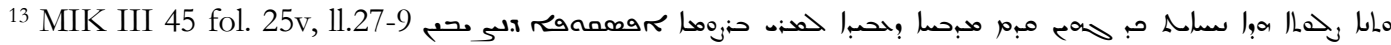
"Whilst bowing before the altar, (the president) repeats quietly this prayer which was composed by Mar Barsauma, bishop of Nisibis". 
returned a dating range, $771-884 \mathrm{CE}$, thus allocating this 61 -folio codex to the $8-9^{\text {th }}$ centuries. Although MIK III 45 is incomplete, the quires of 14-16 leaves indicate that original manuscript might be estimated as being originally some 200 folios. ${ }^{14}$ The folios are inscribed in black ink, with rubric lemmata, in a standard East Syriac script that is derivative of Estrangela. The correct and legible classical text displays only a few non-standard features. ${ }^{15}$ Most notable is the usage of the double points or seyame (indicating plural nouns) with singular nouns, a trend that occurs quite frequently throughout the text. ${ }^{16}$ This idiosyncratic application could denote a provincial pronunciation, but overall the grammar and syntax of the folios conveys the impression that they were written by a scribe (or scribes) who were well-trained in Syriac. Whilst particular mention is made of the saints who were connected with the mission at Marv, the overall contents of MIK III 45 uphold and maintain the liturgical cycle and repertoire of the Church of the East.

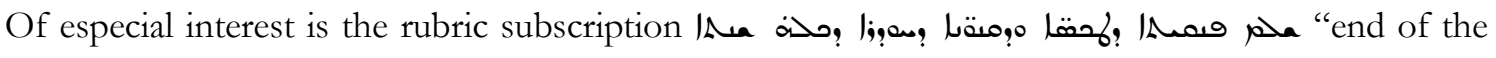
fenqitho (volume) of the orders of service and qanone (i.e. liturgical rules, or rubrics) of the budra (cycle) of the whole year" (fol. 21a ll. 12-13). This denotes that MIK III 45 originally consisted of a full cycle of services for the entire ecclesiastical year. ${ }^{17}$ The $8^{\text {th }}-9^{\text {th }}$ century dating raises the possibility that MIK III 45 is faithful to the Ḥudrā which Patriarch Išo'yabh III (649-659 CE) compiled in the mid-seventh century, but of which no exemplars are now extant. The Hudrā underwent various revisions in subsequent centuries, but Išo 'yabh's work is thought to have included early liturgical material, predating the schisms of the $5^{\text {th }} 6^{\text {th }}$ centuries. As such, the occurrence of /Non fenqitho "volume" in MIK III 45 may attest this phenomenon, since the term later assumed a particular significance, becoming synonymous with the West Syriac tradition. The only other $8^{\text {th }}$ century witness to the Hudrā is a small ostracon that was found during archaeological excavations in 1989 by the Japanese Archaeological Expedition to Iraq at Ain Shaiya, near Najaf. ${ }^{18}$ Sebastian Brock's statement, "the paucity of East Syriac liturgical texts that definitely date from the first millennium renders every scrap of evidence all the

14 Based on the study of the quiring by James F. Coakley, "Manuscript MIK III 45: introduction and questions", paper presented at the 2014 Turfan Workshop, Berlin (July 2014). Unpublished.

${ }^{15}$ Hieronymus Engberding, "Fu $\square$ nf Blätter eines alten ostsyrischen Bitt- und Bussgottesdienstes aus Innerasien," Ostkirchliche Studien 14 (1965), 122-3 gives a succinct account of the physical features of MIK III $/ 45$.

16 This phenomenon is noted where ordinary Syriac words are singular but pronounced as plural, especially where the ending is -e. Selected examples from MIK III 45 include 18), م:ا م: 'Lord of all' (fol. 41 verso: 4). For further discussion, see Erica C.D. Hunter and James F. Coakley, A Syriac Service-Book from Turfan. Museum für Asiatische Kunst MS MIK III 45. The text edited, translated and introduced. (Turnhout, Leuven: Brepols, 2016), 8.

${ }^{17}$ See Plate 1: MIK III/45 fol. 21a.

${ }^{18}$ Erica C.D. Hunter, "Syriac Ostraca from Mesopotamia”, Orientalia Christiana Analecta 256 (1998), 617 39. See also Sebastian P. Brock, "Some Early Witnesses to the East Syriac Liturgical Tradition", Journal of Assyrian Academic Studies 18:1 (2004), 12-13 for a reconstructed reading of the ostracon. 
more valuable" highlights the significance of MIK III $45 .{ }^{19}$

\section{Private Devotion at Turfan: SyrHT 152, SyrHT 99, Syr HT 330, SyrHT 102, n.364-5,}

Syriac prayer-amulets that were found at Turfan provide rare insight into the domain of private devotion and complement the public dimension offered by the liturgy. They also provide the only known examples of iconography amongst the Syriac material. SyrHT 152 (TII B 64 No. $3=1731$ ) is one of only two examples of personal prayer-amulets that have emerged in the Syriac material. Now held in the Staatsbibliothek, Potsdamer Platz, Berlin, ${ }^{20}$ it is a tiny fragment $4.5 \mathrm{~cm}$ (height), $3.9 \mathrm{~cm}$ (width), with only two Syriac words, written vertically in East Syriac Estrangelo script: للرمئ "ffor your handmaid, servant girl" and [i]Lero[i] "healing", ${ }^{21}$ The words flank a well-executed cross of the Church of the East drawn in the centre of the fragment's recto, where it imparts both visual and apotropaic capacities. ${ }^{22}$ The iconography of SyrHT 152 i.e. of the East Syrian cross surmounting a lotus, reiterates the finely worked example on the apex of the Xian Fu stele which was completed in 781 CE. 23

The second example of a cross occurs on the verso of SyrHT 99, although its execution is rudimentary, in comparison to the example on SyrHT 152. SyrHT 99 was physically adapted from a much larger fragment to make the prayer-amulet; its contents ask for God's assistance, mentioning illness and also Lea: "magic, sorceries" but are non sequitur since the trimming of the right-hand margin has meant that the words commencing many of the lines (cf. 1l. 1, 4, 5 7, 8, 9 and 10) are incomplete and frequently consist of only one or two characters. It forms a dislocated join with SyrHT 330, a fragment of 4 lines. ${ }^{24}$ Whilst the intermediate portion between these two fragments has been lost, it is clear that both originally belonged to a much larger folio whose recycling appears to have taken place at the monastery. ${ }^{25}$ What prompted this re-usage, i.e. the conversion of SyrHT 99 as a personal prayer-

${ }_{19}$ Brock, "Some early witnesses", 11.

20 The fragment is now housed in the Staatsbibliothek, Potsdamer Platz, Berlin. SyrHT means that the manuscript (Handschrift $=\mathrm{H}$ ) is Syriac and comes from Turfan (T). T II B means that the fragment was found at the monastery site of Bulayï (B) near Turfan, during the second campaign of the German Turfan Expedition in 1904-1905.

${ }^{21}$ Plate 2 SyrHT 152 recto.

22 The verso is blank.

${ }^{23}$ Cf. the cross at the apex of the Xian Fu stele, see Gillman and Klimkeit, Christians in Asia, Plate 34b for a line drawing.

${ }^{24}$ Plate 3 SyrHT 99 recto \& SyrHT 330 recto.

25 They are now housed in the Staatsbibliothek, Potsdamer Platz, Berlin. For the transliteration, translation and full discussion of these two fragments see, Erica C.D. Hunter, "Traversing Time and Location: A PrayerAmulet to Mar Tamsis from Turfan" in From the Oxus River to the Chinese Shores. Studies on East Syriac Christianity 
amulet is unknown. The larger folio may have deteriorated, but scraps were still deemed to be efficacious. The combined contents of SyrHT 330 and SyrHT 99 show that the erstwhile larger fragment consisted of the prayer of the martyr, Mār Tamsis, who is named in the rubric title of SyrHT 3301.1 . 1.1 "Anathema of Mār Tamsis, the celebrated martyr". Due to the trimming process, SyrHT 99 makes no mention of Mār Tamsis, an omission that may have been deliberate. Alternatively, the exclusion of his name may have just been accidental.

The criteria governing the selection of SyrHT 99 as a personal prayer-amulet remain enigmatic. One factor, might have been the quotation of "John 1:1-4.2" (SyrHT 99 1l.1-3) since the opening verses of the Gospel of John were deemed to have a particular efficacy. ${ }^{26}$ Unlike SyrHT 152 which identifies the recipient as a 'handmaid', SyrHT 99 provides no clue as to the identity of the person for whom it was prepared, but the still visible creasemarks which indicate that the fragment was folded into three, suggest a portable personal item. The rudimentary cross of the Church of the East, which has been drawn free-hand in the central panel of the otherwise blank verso, may have 'sealed' the precious contents as well as being an indicator as to how to carry the prayer-amulet. This might have been a necessary measure if the intended recipient was illiterate or unable to read Syriac, as one might expect of the laity at Turfan who spoke Sogdian or Uighur. ${ }^{27}$ On the other hand, SyrHT 99 might have been produced by one of the monks at the monastery, for his private devotion.

The subject of SyrHT 330, Mār Tamsis is not mentioned in the liturgical fragments from Turfan, but his commemoration in the Church of the East calendar was on the $8^{\text {th }}$ Wednesday after Epiphany. ${ }^{28}$ B.L. 14653 , a $9^{\text {th }}$ century manuscript from northern Mesopotamia, which details the lives of numerous saints, also includes a prayer to Mār Tamsis, ${ }^{29}$ that occurs just before the colophon which names the scribe as 'Saliba'. No other details are supplied. Interestingly, Mār Tamsis was commemorated in

in Central Asia and China. Edited by Dietmar Winkler and Li Tang [Orientalia-patristica-oecumenica v. 5] (Lit. Verlag: Salzburg, 2013), 23-41.

26 These verses and were still used to introduce the handbooks of amulets that were used by the Syriac Christians in the $19^{\text {th }}$ and $20^{\text {th }}$ centuries. See Hermann Gollancz, The Book of Protection, being a collection of charms (London: H. Froude, 1912) for examples of this practice.

${ }^{27}$ N. Sims-Williams, "Sogdian and Turkish Christians in the Turfan and Tun-huang manuscripts", Turfan and Tun-buang: the texts, Edited by Alfredo Cadonna, (Florence: Olschki, 1992), 43-61.

${ }^{28}$ See معز; (Surgada Mbašla) (Urmi: Press of the Archbishop of Canterbury's Mission, 1894) 8. This commemoration occurs only occasionally since there are usually only seven Wednesdays after Epiphany. The author thanks Rev. Giwargis Malco Khoshaba (Ancient Assyrian Church of the East, London) for this information. For further information about this perpetual calendar, see James F. Coakley, "The Archbishop of Canterbury's Assyrian Mission Press: A Bibliography." Journal of Semitic Studies 30:1 (1983) 52-53, which notes that the perpetual calendar consisted of 38 pages, with pp. 5-9 being lists of festivals and saints' days, 'taken from a MS 550 years old'. This manuscript which was written in 1443 and is now lost is mentioned by Arthur J. Maclean and William H. Browne, The Catholicos of the East and his People (London: SPCK, 1892) 347.

${ }^{29}$ See Hunter, Traversing Time and Location, 34-35 for the text and translation of this prayer-amulet. 
handbooks of amulets dating from the eighteenth and nineteenth centuries that were used by the Syriac Christian communities in Hakkari. ${ }^{30}$ Mingana Ms. Syr 316, whose colophon was written in 'the year 2088 of the Greeks' i.e. between October of 1776 and September of 1777, mentions his name in connection with an amulet against lunacy that was entitled /;0س "Of "Of the daughter of the moon". ${ }^{31}$ Mār Tamsis is named as a celebrated martyr and, in keeping with SyrHT 330, Mingana Ms. Syr 316

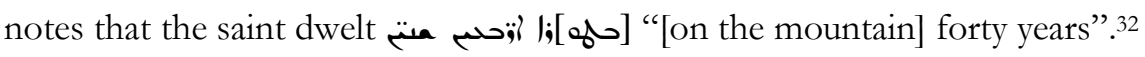

Mar Cyprian was also commemorated in the $19^{\text {th }}$ century handbooks and at Turfan where he is the subject of two prayer-amulets. n.364-365 now deposited in the Turfanforschung, Berlin-Brandenburg Akademie der Wissenschaft, Berlin, ${ }^{33}$ are dislocated fragments, but derive from the same folio, where the intermediate contents have been lost. The upper half of the recto of n.364 has nine lines of an anathema to Mār Cyprian, with a miscellany of later, unrelated texts covering the bottom half of the recto and the verso side. ${ }^{34}$ n.365 consists of 6 lines that correspond to $11.1-6$ of n.364 and forms the right-hand side of the original folio. Written in East Syriac Estrangela, each word of n.364 11.1-9 and n.365 1l.1-6 is separated by a red dot. The (right-hand) margin of $\mathrm{n} .365$ has been lost, but a red dot concludes the end of n.364 11.3-9, producing a justified left-hand margin. Red-black paragraphii have been placed at the end of n.364 11.1-2; with the paragraphus of 1.1 coming at the end of the anathema's rubric heading. The application of the rubric dots (very helpful in reading the text) is unique and does not occur in any of the other fragments from Turfan. This demarcation of each word must have imparted a visual, and possibly apotropaic, impact. Additionally, the originally blank verso (also a feature of SyrHT 152 and SyrHT 99 \& SyrHT 330) points to n.364-365 being specifically prepared as an amulet, with a subsequent re-cycling at a later date.

\section{Text and transliteration: $\mathbf{n} .364-365$}

Recto: ${ }^{35}$

${ }^{30}$ For details of the other handbooks of amulets, dating from 1779-1817 that include "The anathema of Mar Tamsis which is suitable for the daughter of the moon" see Hunter, Traversing Time and Location, 30.

${ }^{31}$ Mingana Syr. Ms. 316 fol. 61a-64a. Mingana Syr. Ms. 316 folio 61, verso for a graphic illustration of the mounted saint lancing a one-eyed demoness.

32 Mingana Syr. Ms. 316 fol. 62a 1.2 oa loa "who dwelt" + fol. 62a 1l.3-4 حمه "in/on the mountains for forty years".

${ }^{33}$ Plate 4 n364-365 with the labels n364 and n365 having been inserted upside down to the text.

34 Aside from the anathema to Mār Cyprian, n364-5 recto consists of various contents: (a) two lines of text in Sogdian (written in Syriac script), (b) 4 lines of Syriac, in a different hand. n364-365 verso has a Sogdian text, written in Syriac script.

${ }^{35}$ Bold type indicates rubrics in the Syriac text and the translation. 


\begin{tabular}{|c|c|}
\hline $1.1[\ldots] \mathrm{hr}(\mathrm{m})^{\prime} \mathrm{d}[\mathrm{mry}] \mathrm{qp}[\mathrm{ry}] \mathrm{n}^{\prime}$ qdyš' & 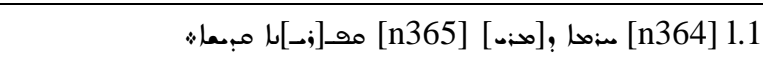 \\
\hline 1.2 [bšm] 'b' br[' wrwḥ' dq]wdš' l'lmyn 'myn & 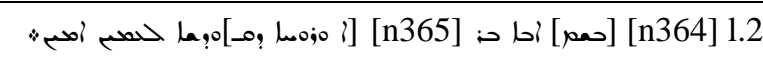 \\
\hline 1.3 bṣlwth d[mry qpryn'] qdyš' d'ykn 'tnșy & 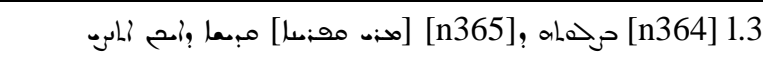 \\
\hline 1.4 b'lm’ y(n)’ s’'1 [...] mn mrn yšw' mšyh’ wyh & 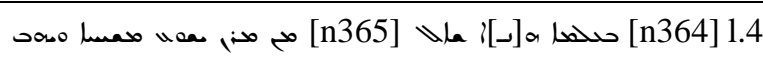 \\
\hline 1.5 lh 'lh' š'lth [...] šwbh' lk 'lh' bšmy' & 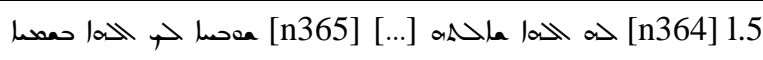 \\
\hline 1.6 (w)b' ( )' [...] ( )b' dn't'? bh 'bdk & 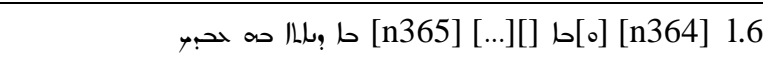 \\
\hline $1.7[\ldots]$ h'lh' mrym' hydyn mry & 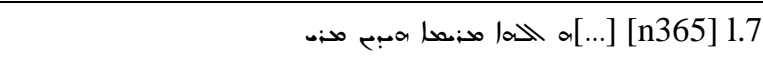 \\
\hline 1.8 [qpryn'] mth r'yn' lwt 'lh' hš' & 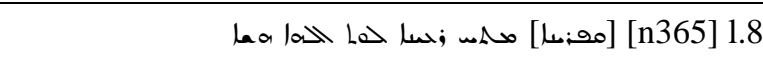 \\
\hline $1.9[\ldots]$ [..yn mry' & (n365] 1.9 \\
\hline
\end{tabular}

\section{Translation:}

\section{The anathema of the holy ... [Mār] Cyp[ria]n}

2. [In the name] of the Father Son [and Holy Spirit] forever. Amen.

3. By the prayer of [Mār Cyprian] the saint ... who as he was celebrated

4. in this world ... requested from our Lord Jesus Christ and He gave

5. him his request ... Praise to you God in heaven

6. and on [earth] ... that He might reach(?) him, your servant

7. ... God Most High. Mār

8. [Cyprian] offered $<$ his $>$ mind to God. Now

9. ... Yea, Lord

SyrHT 102 is the second example of a prayer-amulet dedicated to Mār Cyprian. A single leaf, measuring 11.00 x $9.9 \mathrm{~cm}$, it is now housed in the Staatsbibliothek, Potsdamer Platz, Berlin. ${ }^{36}$ Written in East Syriac Estrangelo, there are 11 lines of text on the recto and 10 lines on the verso. The anathema to Mār Cyprian commences on the recto 1.2.

\section{Text and transliteration: SyrHT 102}

Recto: 37

\begin{tabular}{|c|c|}
\hline $1.2[\mathrm{~h}] \mathrm{rm}$ ' d ... mry qwpryn' qdyš' & 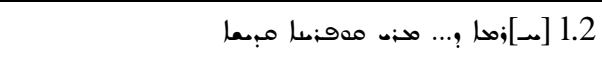 \\
\hline 1.3 d'kyn 'tnșḥ b 'lm' hn' [šs]'l mn & 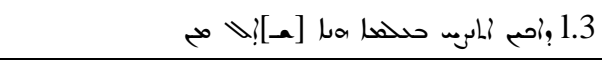 \\
\hline 1.4 'lh' wyḥb lh s'lth kd 'mr hkn' & 1.4 الحما \\
\hline 1.5 bywm' dyn qdyš' dḥd b[šb'] dbh mštryn 'bry[n] & 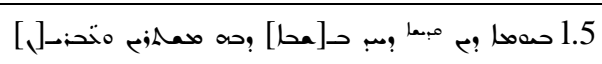 \\
\hline 1.6 wbṭlyn klhwn [g]br' byš’ wškyr' wsny' & 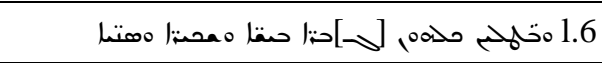 \\
\hline 1.7 brw d'[lh]' mry[m]' hwdyn qdyš' & 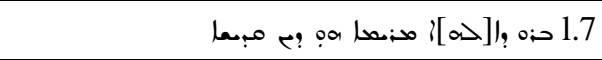 \\
\hline 1.8 mry qwpryn' mtḥ hwnh & 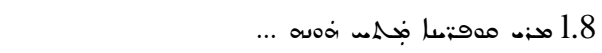 \\
\hline
\end{tabular}

${ }^{36}$ See Plate 5 A SyrHT 102 recto and Plate 5B SyrHT 102 verso.

${ }^{37}$ Bold type indicates rubrics in the Syriac text and the translation of the recto and verso. 


\begin{tabular}{|c|c|}
\hline 1.9 'lh' ... wb' ' $1 \ldots$ & 1.9 الدها ... محدا 7. \\
\hline $1.10^{\prime}$ 'šwbh' 1 [k 'lh'] & [1.10 \\
\hline
\end{tabular}

\section{Translation:}

1.2 The anathema of ... the holy Mār Cyprian,

1.3 when he was celebrated in this world, he requested from

1.4 God and He granted him his request. Whilst he said thus:

1.5 On the holy day, Sunday are loosened, passed over

1.6 and voided, all those wicked, vile and hateful men.

1.7 ... God Most High. Then the saint

1.8 Mār Cyprian directed his mind

1.9 God ... and sought ...

$1.10 \ldots$ praise to [you God] ...

Verso:

\begin{tabular}{|c|c|}
\hline 1.1 [']l[h]' šwbḥ' lk 'lh' [...] wb['r ']' & i 1.1 \\
\hline 1.2 'hyd kl wmdbr kl bhyl' bš[m]h qdyš’ & 1.2 أسب مل همبد: ملا حسلا بج[مـ][ه مبمعا \\
\hline 1.3 mšbḥ' mlk' dmlk' wmr' dmrwth’ d'mr & 1.3 معحسا محدا بقحدا مهد:| ومتهما| وتصد: \\
\hline 1.4 bnwhr' g'y' ksy' wgnyz' hw d'nš mn & 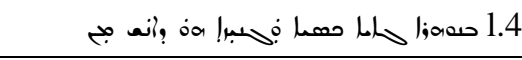 \\
\hline 1.5 bnynš' l' ḥzyhy w’pl' mṣ' lmḥzyhy & 1.5 \\
\hline 1.6 'nt mry yd' 'nt ksyth d'bdk 'n' & 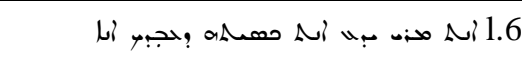 \\
\hline 1.7 ... qdym zbn’ b'wz' dm‘bdnwthwn & 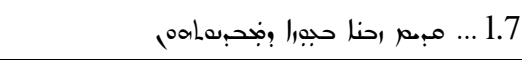 \\
\hline 1.8 ... wmhrm’ dpšr hwyt kl nḩ̌šyn & 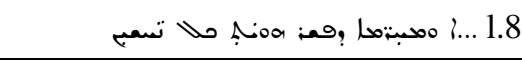 \\
\hline 1.9 ... qșmyn kd l’ yd‘ hwyt lk & 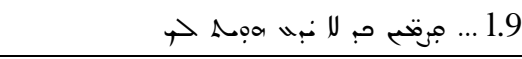 \\
\hline 1. 10 ... wl' nḥtn mțr' wl' 'r ['] & 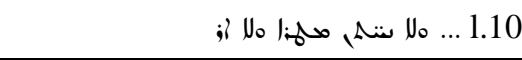 \\
\hline 1. 11 ... šmy' wl'r ' $\mathrm{dl}^{\prime}$ & 1.11 \\
\hline
\end{tabular}

\section{Translation:}

1.1 God. . Praise to you God [.]... On earth

1.2 He holds all and rules all by the power, by His holy

1.3 and glorious name. King of kings and Lord of the Lords who dwells

1.4 in the joyous, hidden and mystic light. He whom

1.5 no man has seen nor is even able to see him.

1.6 You, Lord, you know the secret of your servant. I

$1.7 \ldots$ before time, the violence of their (magical) practice

$1.8 \ldots$ and execrable that you have dissolved all divinations

1.9 ... augurers. Whilst I did not know you

$1.10 \ldots$ neither falls rain nor the (earth)?

$1.11 \ldots$ heaven and earth lest 
Both SyrHT 102 and n364-365 begin with the technical term, سنمدا "anathema", signifying a prayer that was always used in conjunction with a named saint who uttered it at the point of martyrdom..$^{38}$

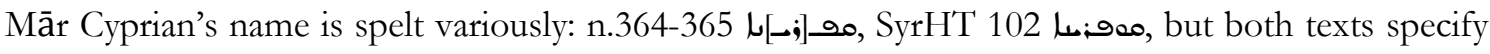

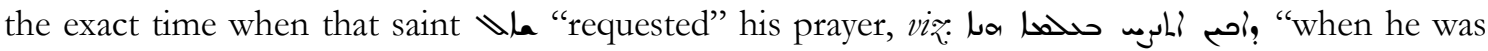
celebrated in this world" i.e. at the point of his martyrdom. ${ }^{39}$ SyrHT 102 and n364-365 specifically state that Mār Cyprian's wish was granted: a a a "and He gave him his request", ${ }^{40}$ but the contents of Mār Cyprian's prayer in SyrHT 102 are much longer than n364-365 (where there are textual lacunae) and notably include several clear references to the dissipation of magic and divination on 1l. 5-6 and 11. 8-9. Both n364 and SyrHT 102, in the concluding parts of the prayer, cite the clause,

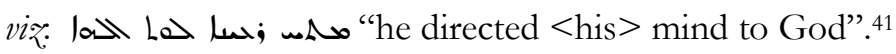

The physical format of n.364-365 suggests that it may originally have been prepared as a personal amulet. By contrast, "The anathema of Mār Cyprian" in SyrHT 102 follows immediately after the

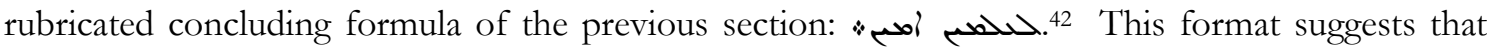
SyrHT 102 may have been part of a 'handbook of prayer-amulets', which monks used and consulted at Turfan; a tradition that continued as late as the 19th century amongst the Syriac-speaking clergy of Hakkari. The anathema of Mār Cyprian is found in various manuscripts, including the aforementioned Mingana Syr. Ms. 316, where it is listed under the rubricated heading "the anathema of Mār Cyprian, the celebrated martyr". The text of Mingana Syr. Ms. 316 is much longer than both n.364-365 and SyrHT 102,43 but it does exhibit

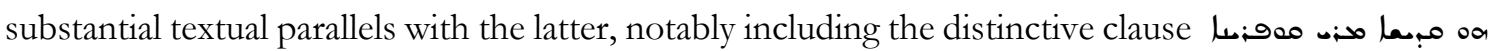
"Mār Cyprian, the saint, directed (his) mind to the Lord of All". ${ }^{44}$ "The colophon

${ }^{38}$ SyrHT 102 recto, 1.2; n364-365 1.1. For a discussion of the 'anathema' genre, see Erica C.D. Hunter, "Saints in Syriac Anathemas: A Form-Critical Analysis of Role", Journal Semitic Studies, 37: 1 (1987), 83-104.

${ }^{39}$ SyrHT 102 recto 1.3, n364-365 11.3-4.

40 SyrHT 102 recto 1.4, n364-365 1.4.

${ }^{41}$ SyrHT 102 recto 1.8 and n365 1. 8. For مـw see Michael Sokoloff, A Syriac Lexicon (Winona Lake, Piscataway: Eisenbrauns, Gorgias, 2009), 863 citing William Wright, Apocryphal Acts of the Apostles, 2 vols., (London: 1865) 223:19, Jessie Payne-Smith, A Compendious Syriac Dictionary (Oxford: Clarendon, 1903), 314.

${ }^{42}$ SyrHT 102 recto 1.1. The contents of the previous section, which was written on the preceding folio to SyrHT 102, have not survived.

${ }^{43}$ See Hunter, Saints in Syriac Anathemas, 100-3 for the text and translation of this anathema in Mingana Syr. Ms. 316, fol. 21r-26r.

${ }^{44}$ Hunter, Saints in Syriac Anathemas, 100 (text), 102 (translation), with the small change of الحما 
of Mingana Syr. Ms 316 names the village of Marshanis in the Atel district, in the diocese of Buhtan in the Seert region, as the place of its production. ${ }^{45}$

\section{Concluding Comments:}

The selected manuscripts respectively demonstrate the public and private dimensions of faith that took place at Turfan in the medieval period. In this remote outpost, the heritage of the Church of the East was robustly maintained; the public worship i.e. the liturgy looked westwards to Mesopotamia, as did the private devotions, i.e. the prayer-amulets. This trajectory is epitomized by the usage in both public worship and private devotion of Syriac, which would have been largely unfamiliar to the Sogdian and Uighur-speaking laity, but maintained a particular sanctity and efficacy. The dating of MIK III 45 that places it shortly after the mid-7th century compilation of the Hudrā by Patriarch Isoyabh III, provides unparalleled insight into the East Syrian liturgy of the first millennium and its dissemination in the far-flung dioceses of the Church of the East. The prayer-amulets are rare vernacular items illuminating the stratum of personal devotion to saints who were inextricably connected with Mesopotamia. Although their dating has not been secured, their presence at Turfan indicates that they predate -by some six or seven centuries- namesake anathemas that were still in usage amongst the Syriac-speaking communities of Hakkari until their tragic demise in the Sayfo of 1915. Paradoxically, just a few years prior the German Turfan Expedition made spectacular discoveries at Turfan and opened new dimensions in our knowledge of the spread of East Syrian Christianity.

${ }^{45}$ For further information about Marshanis, see David Wilmshurst, The ecclesiastical organisation of the Church of the East, 1318-1913 (Leuven: Peeters, 2000), 90, 98 and Map 2: west of Deh and east of Tal. See also, the online entry by Thomas A. Carlson, "Marshanis - مـace" in The Syriac Gazetteer, Edited by Thomas A. Carlson and David A. Michelson, entry published May 10, 2014, Syriaca.org: The Syriac Reference Portal, Edited by David A. Michelson. Justin Sheil, "Notes on a journey from Tabriz through Kurdistan via Van, Bitlis, Se'ert and Erbil through Suleimaniyeh in July and August 1836", Journal of the Royal Geographical Society of London 8 (1838) 67 cites the towns of Amadiyeh and Se'ert as the eastern and western boundaries of Buhtan. 


\section{BIBLIOGRAPHY:}

Boyce, Mary, ed. A Catalogue of the Iranian Manuscripts in Manichaean Script in the German Turfan Collection. (Deutsche Akademie der Wissenschaften zu Berlin, Institut für Orientforschung, Veröffentlichung Nr. 45), Berlin: Akademie Wissenschaften, 1960.

Brock, Sebastian P. "Some Early Witnesses to the East Syriac Liturgical Tradition." Journal of Assyrian Academic Studies 18:1 (2004): 9-54.

Budge, Ernest A.W. Histories of Rabban Hormîgd the Persian and Rabban Bar-Tdtâ. 2 vols. London: Luzac, 1902.

Coakley, John F. "Manuscript MIK III 45: introduction and questions". Unpublished paper presented at the 2014 Turfan Workshop, Berlin (July 2014).

Dickens, Mark, “Syro-Uigurica II: Syriac passages in U338 from Turfan.” Hugoye 16:2 (2013): 301-24.

Dickens, Mark \& Peter Zieme, "Syro-Uigurica I: A Syriac Psalter in Uyghur Script from Turfan” Pages 291-328 in Scripts Beyond Borders. A Survey of Allographic Traditions in the Euro-Mediterranean World. Edited by Johannes den Heijer et al. Leuven: Peeters, 2014.

Engberding, Hieronymus, "Fu $\square$ nf Blätter eines alten ostsyrischen Bitt- und Bussgottesdienstes aus Innerasien." Ostkirchliche Studien 14 (1965): 121-48.

Gillman, Ian \& Hans- Joachim Klimkeit, Christians in Asia before 1500. London: Curzon, 1999.

Gollancz, Hermann, The Book of Protection, being a collection of charms (London: H. Froude, 1912).

Hunter, Erica C.D. "Saints in Syriac Anathemas: A Form-Critical Analysis of Role." Journal Semitic Studies, 37:1 (1987): 83-104.

Hunter, Erica C.D. “Syriac Ostraca from Mesopotamia.” Orientalia Christiana Analecta 256 (1998): 617-39.

Hunter, Erica C.D. “Traversing Time and Location: A Prayer-Amulet to Mar Tamsis from Turfan” Pages 2341 in From the Oxus River to the Chinese Shores. Studies on East Syriac Christianity in Central Asia and China. Edited by Dietmar Winkler and Li Tang [Orientalia-patristica-oecumenica v. 5] Salzburg: Lit. Verlag, 2013.

Hunter, Erica C.D. and James F. Coakley, A Syriac Service-Book from Turfan. Museum für Asiatische Kunst MS MIK III 45. The text edited, translated and introduced. Turnhout, Leuven: Brepols, 2017.

Hunter, Erica C.D. and Mark Dickens, eds. Syrische Handschriften, Teil 2. Texte der Berliner Turfansammlung. Syriac texts from the Berlin Turfan collection. Stuttgart: Steiner Verlag, 2014.

Le Coq, Albert von Buried Treasures of Chinese Turkestan. Trans. Anna Barwell, London: George Allen and Unwin Ltd, 1928.

Maclean, Arthur J. and William H. Browne. The Catholicos of the East and His People. London: SPCK, 1892.

Macomber, William F. "A List of the Known Manuscripts of the Chaldean Hudra.” Orientalia Christiana Periodica 36:1 (1970): 120-34.

Meshcherskaya, Elena N. "The Syriac Fragments in the N. N. Krotkov Collection” Pages 221-7 in Turfan, Khotan und Dunhuang. Edited by Ronald E. Emmerick et al. Berlin: Akademie Verlag, 1996.

Mu $\square$ ller, Friedrich W.K. "Soghdische Texte I”, SPAW 1912 (1913): 84-8.

Payne-Smith, Jessie. A Compendious Syriac Dictionary. Oxford: Clarendon, 1903.

Sachau, Eduard. "Litteratur - Bruchstu $\square$ cke aus Chinesisch - Turkistan”, Sitzungsberichte der Königlich Preussischen Akademie der Wissenschaften (Sitzung der philosophisch - historischen Classe von 23. November) XLVII 
(1905): 964-73.

Saeki, Peter Yoshira. The Nestorian Documents and Relics in China. Tokyo: Maruzen, 1937.

Sheil, Justin. "Notes on a journey from Tabriz through Kurdistan via Van, Bitlis, Se'ert and Erbil through Suleimaniyeh in July and August 1836", Journal of the Royal Geographical Society of London 8 (1838): 54-101.

Sims-Williams, N. "Sogdian and Turkish Christians in the Turfan and Tun-huang manuscripts" Pages 43-61 in Turfan and Tun-huang: the texts. Edited by Alfredo Cadonna, Florence: Olschki, 1992, 43-61.

Sokoloff, Michael. A Syriac Lexicon. Winona Lake, Piscataway: Eisenbrauns, Gorgias, 2009.

Wilmshurst, David. The Ecclesiastical Organisation of the Church of the East, 1318-1913. Leuven: Peeters, 2000.

The Syriac Gazetteer, by Thomas A. Carlson and David A. Michelson, entry published May 10, 2014, Syriaca.org: The Syriac Reference Portal, ed. David A. Michelson. 